\title{
CRL optics and silicon drift detector for P06 Microprobe experiments at $35 \mathrm{keV}$ - ERRATUM
} Gerald Falkenberg, Frank Seiboth, Frieder Koch, Ken Vidar Falch, Andreas Schropp, Dennis Brückner, and
Jan Garrevoet

C The Author(s), 2020. Published by Cambridge University Press on behalf of International Centre for Diffraction Data. This is an Open Access article, distributed under the terms of the Creative Commons Attribution licence (http://creativecommons.org/licenses/by/4.0/), which permits unrestricted re-use, distribution, and reproduction in any medium, provided the original work is properly cited

doi: https://doi.org/10.1017/S0885715620000536, Published by Cambridge University Press, 5 August 2020
Falkenberg et al. (2020) published with the incorrect article type.

The correct article type is Proceedings Paper. The online version of the article has been updated.

The editor apologizes for this error.

Falkenberg, G., Seiboth, F., Koch, F., Falch, K. V., Schropp, A., Brückner, D., and Garrevoet, J. (2020). "CRL optics and silicon drift detector for P06 Microprobe experiments at $35 \mathrm{keV}$," Powder Diffr. 35, S34-S37. doi:10.1017/S0885715620000536. 